\title{
Figurative Language in Malay to English Translation: An Analysis of the 2015 UniMAP VC's Keynote Speech
}

\author{
Sharmini A. ${ }^{1}$, Muhammad Bazli Mahmood ${ }^{1}$, Khairul Hisham Jamalludin ${ }^{1}$, Ahmad Hifzurrahaman Ridzuan ${ }^{1}$, Mohamad Zaki \\ Abdul Halim ${ }^{1}$, Siti Nurul Jannah Fital ${ }^{1}$ \\ ${ }^{1}$ Centre of International Language, Universiti Malaysia Perlis (UniMAP), Malaysia.
}

\begin{abstract}
Translating figurative language involves more than just replacing the figurative language with its equivalent in the target language. Therefore, it is not surprising for the translation of figurative language to have its own set of challenges. Problems the translator faces in translating the Malay Figurative Language into English include complexities in understanding, interpreting and recreating the Figurative language that are unique in the Source Language (SL) culture; which have to be explained and described in Target Language (TL) where such practices and customs are non - existent. Secondly, the Source Text (ST) figurative language may appear in a variety of types and have a distinct denotative and connotative meaning and reference; most often, it is difficult to find an equivalent which totally matches the original meaning or concept. This particular paper analyses the translation of figurative language extracted from UniMAP's Vice Chancellor Keynote Speech in 2015. Findings reveal that the three categories of figurative language identified were namely idioms, metaphors and similes. Translation strategies used are either not translated, paraphrased or translated with a similar meaning but in different form.
\end{abstract}

\section{Introduction}

Figurative Language according to Montgomery et al (2007) refers to the state of words or phrases that implies a non-literal meaning which does make sense or that could [also] be true. This notion is strongly supported by Nida (1975) who explains figurative word as a word which is used in place of another meaning or expression which is not its synonym but with which it has an association of ideas often mediated through a supplementary component such as idioms, simile and metaphors ». In short, figurative language occurs whenever an individual describes something by comparing it with something else.

Within the translation context, we can infer that figurative language may play an important role in the explanation of cultural concepts or can be used as the substitution of one idea or object with another, and to assist expression or understanding. However, translating figurative language is more than just handling terminology. In agreement with Abdul Wahid (2017, p. 17), "translating figurative language not only requires the knowledge of the language and cultures of both source and target language, but also choosing the appropriate word and translation strategies". Thus, the main challenge of translating figurative language lies in grasping the ST author's cultural meaning and transmitting that cultural meaning which is expressed via a figurative word into another language as accurately as possible in the way in which the SL author would most probably have expressed the content himself or herself, had he or she been a native speaker of the target language (Abdullah, 2014). In other words, the target language is presented in an accurate possible form, complete and that the information can be used correctly and effectively.

Bell (1991) stresses this challenging process of translating when he mentions that it is "very clear that the ideal of total equivalence is impossible in translation because languages are different from each other, they have different codes and rules regulating the construction of grammatical forms which have different meanings". (p. 6). Both Jakobson (1976) and Bassnett (1980) also emphasize this point. Jakobson (1976) believes there are "no exact synonyms between languages" (p. 26). Bassnett (1980) echoes this notion when she states that there cannot be complete equivalence in translation as "each unit contains within itself a set of non-transferable associations and connotations" (p. 15). She explains further that "sameness cannot even exist between two target language versions of the same text" (p. 29).

As such, translating figurative involves more than just replacing the figurative language with its equivalent in another language. Translating figurative language from Malay (source language, or SL) to English (target language, or TL) will require more than just reformulating the figurative word in one language (i.e. Malay) as a figurative word in a different language (i.e. English). This paper attempts to discuss the translation of figurative language namely idioms, metaphors and similes when translated from Malay to English, factors that influence the translation procedures used by the 
translator and bring to light the possibilities and challenges of translating figurative language from Malay into English using examples extracted from the 2015 UniMAP VCees KeynoteSpeech.

\section{Literature Review}

\subsection{Translation}

Newmark (1981) defines translation as a "craft consisting of the attempt to replace a written message and/or statement in one language by the same message and / or statement in another language" (p. 7). Bell (1991) further amplifies this definition in his interpretation of translation - "to produce as accurately as possible all grammatical and lexical features of the source language (SL) original by finding the equivalences in the target language". At the same time all factual information contained in the original text must be retained in the translation" (p. 13). These prescriptive definitions above highlight features of translation as either a product (the text that has been translated) or the process (the act of producing the translation).Translation as a process based on Hatim and Mundayees (2004) definition refers to "the role of the translator in taking the original or ST and turning it into a text in another language, the target text TT" (p. 3). Translation as a product on the other hand, "centres on the concrete translation product produced by the translator" (Hatim \& Munday, 2004, p. 6).

Shuttleworth and Cowie (1997/2014) provides a more comprehensive definition as their definition incorporates a wider range of areas in translation - "an incredibly broad notion which can be understood in many different ways. For example, one may talk of translation as a process or product, and identify such sub types as literary translation, technical translation, subtitling and machine translation; moreover, while more typically it just refers to the transfer of written texts, the term sometimes also includes interpreting" (p. 183). For the purposes of this paper, the term translation will be used to refer to "a text containing instances of substitution, addition, omission, expansion, or modification and produced on the basis of a source text in the target language in terms of words, meaning, or sentence structure with the main purpose of making the target text suitable for a particular purpose, genre and audience" (Abdullah \& Shuttleworth, 2013, 3(6), p. 608).

\subsection{Equivalence in Translation}

Identifying, selecting and creating an equivalent in the TL is not always an easy task. As such, translators would have to either alter, expand or omit items in their translations. The process of translating an SL is always to identify the suitable equivalents in the TL first. Shuttleworth \& Cowie (1997) define equivalence (or Translation Equivalence) as "the nature and the extent of the relationships which exist between SL and TL texts or smaller linguistic units" (p. 49). These "smaller linguistic units" include levels of equivalents which range from the least significant level of language - that of morpheme - to the more complicated levels like a sentence between the SL and TL. It is not surprising that equivalence in translation is described as a "troubled notion" (Hermans, 1995, p. 217) because most translation scholars like Jakobson (1959/1966), Nida (1964/1969), Catford (1965), House (1977), Baker (1992), Vinay and Darbelnet (1995) express their understanding and interpretation of translation equivalence differently. However, regardless of the difference in views and interpretations, all unanimously suggest the fundamental role of equivalence - culturally and linguistically in the translation process. They view equivalence as a technique which reproduces the same situation in the TL as in the original; only with a completely different wording. They also mentioned that equivalence is the ideal method in dealing with figurative languages like idioms, clichés and proverbs.

It must be noted however, that this perception when applied now is somewhat old fashioned (Abdullah, 2014). "Translation is no longer determined by the principle of equivalence, but based on the adequacy in aacordance with the directions of translation. However, the production of the translation must be logical or coherent" (Abdul Wahid, 2017, p.3). Abdul Wahid's statement above mirrors Nord ${ }^{\text {ee }}$ (2001) functionalist approach in translation. According to Nord (2001) each translation process does not only translate the language, but also the concept of a term in the source text.

Similarly, Vermeer (cited in Nord, 1997) implies that translation is a purposeful activity. "Any form of translational action, may be conceived as an action. Any action has an aim, a purpose" (p.12). Newmark (1988a) and Nord (1997) agree with Vermeer and further explain that if the aim of the commissioner is to convey the cultural aspects of the ST, then the translator will place more emphasize on the precise wording that it contains. If the purpose is to ensure that the translation conveys the same emotional and persuasive tones as the ST, the translator will then apply another set of strategies to help the target readers to achieve a better understanding of that textual level.

\subsection{Translatability of Figurative Language}

The translatability of figurative language has always been questioned as pointed out by Dagut (1976) and Newmark (1988a) below:

"The crucial question that arises is thus whether a metaphor can, strictly speaking, be translated as such, or whether it can only be "reproduced" in some way" Dagut, M. B. (1976, p. 24).

"whilst the central problem of translation is the overall choice of a translation method for a text, the most important particular problem is the translation of the metaphor" (Newmark, 1988a, p. 104). 
The lack of clarity in figurative language makes translating and interpreting its meaning not always easy and straightforward. In translating figurative language from one language and culture to another, one may be hampered by linguistic and cultural differences between the two (or more) languages concerned. As such, translating figurative language can give rise to various challenges and this is predominantly so if the figurative in the source language are culture-bound as in the case of Malay to English Translation of figurative language. This means, that the translation of the figurative language may largely depend on the cultural associations (Dagut, 1976, p. 32; Bassnett, 1980 ; Snell Hornby, 1988/1995, p. 58, Abdullah, 2014, Abdul Wahid, 2017). Figurative language in the Malay language is aimed at expressing something implicitly and to create an impact on its target audience. As discussed above, challenges in translating figurative language arises due to cultural differences between the Malay and English texts.

Baker (1992) highlights four challenges in translating figurative language - i) a figurative language has no equivalent in the target language; ii) a figure of speech might have the same equivalent in the target language, but may vary with the context; iii) a figure of speech in the source language may be translated literally and idiomatic in the target language; iv) the use of figurative language in writing discourse, context and frequency of usage may differ with the source language and the target language.

In overcoming these four challenges, Baker (1992) suggests two translation procedures for translating the figurative language - i) using a figure of speech that is similar in meaning and form; ii) the use of figurative language is similar in meaning, but differ in form and the last is translated by the paraphrase. Baker (1992) further adds translation by paraphrasing is used when an equivalent match cannot be found in the TL (target language).

\subsection{Previous Studies}

Studies which discuss the issues of translating figurative language from Malay to English are a few. Available studies relating to figurative language dealt with translation of metaphors from English to Malay concern Malay poetry (Shunmugam, 2007), Malay figures of speech (Wan Ramli, 2014), classical Malay (Subagiharti, H.et al, 2015).

Shunmugam (2007) examined Malay into English pantun (poetry) translations of two women writers Katherine Sim and Martha Blanche from the nineteenth century to the present times. Shunmugam investigated translation styles adopted by the translators and the extent to which skopos or translation purpose influenced the translation style. She conducted a comparative analysis of Lewis's and Sim's poetry translations with
Wilkinson"s, Winstedt"s and Hamilton"s renditions. Findings indicate that Lewis"s and Sim"s translational styles are not distinctly different from the male British translators of their time.

Wan Ramli (2014), conducted a comparative study of English Similes and their translations of The Hunger Games. Strategies employed by the translator in translating the simile was analysed using strategies proposed by Pierini (2007). Findings revealed that out of the four identified strategies (i.e. literal translation, reduction of the simile, if idiomatic, to its sense, retention of the same vehicle plus explicitation of similarity feature(s) and omission of the simile) Literal translation seems to be the most used strategy by the translator. Wan Ramli concluded this is so probably because some of the similes could be understood and interpreted the same way in Malay. She adds translators did encounter problems in determining the Malay interpretation which conveyed the same meaning as in the SL. Wan Ramli (2014) highlighted the importance of conveying the SL meaning to the target readers rather than providing and accurate translation of the ST. Translators had a choice either to preserve the form or render the meaning by changing the form as long as the meaning is conveyed to the target readers.

On a slightly different note, Subagiharti, $\mathrm{H}$. et al. (2015)'s research on Malay to English metaphor translation focused on the use of anthropomorphemic metaphors in Hikajat Abdullah (Abdullah Tales). Analysis revealed that the anthropomorphemic metaphors in classical Malay displayed specific characteristics as listed below and the form of metaphor in Hikajat Abdullah is determined by the target element:

1. The sentences are long, repetitive, and convoluted.

2. There are many passive sentences with specific vocabularies such as Ratna Mutu manikam, Masyghul (sad).

2. Many sentences are preceded by certain conjunctions, for example, sebermula ,in the beginning," Once, Hatta, while, then, said sahibul saga, when, and while. 4. The sentences are rich of suffixes.

The relatively low number of existing studies related to figurative language in Malay to English Translation as discussed above justifies the need to conduct such studies in this area. Findings from this study will fill the gap in the literature, provide an insight on how and if the figurative language are translated and disclose current figurative language translation practices of the Malay to English Translators.

\section{Methodology}

The main aim of this study is to analyse the translation and translation procedures adopted by the TL translators to translate figurative language using examples extracted from the 2015 UniMAP VC's Keynote Speech. The 
source text (ST) comprises of "Ucaptama Tahunan Naib Canselor 2015: "Mencarik Adat, Melarik Hasrat" while the target text (TT) consist of the slide presentation projected during the event. Translation Text : Slide presentation projected during the event. The methodology adopted is textual analysis whereby Hartmann "es (1980) Parallel Texts Technique and Lindquist"e (1989) Parallel Reading were applied to extract the figurative words from the texts. Bakers (1992) proposed two translation procedures as described in section 2.3 were employed to identify the translation procedures used by the TL translator.

\section{Findings and Discussions}

\subsection{Types of Figurative Language}

Analysis revealed the use figurative language in the UniMAP $2015 \mathrm{VC}^{\mathrm{ee}} \mathrm{s}$ Keynote Speech and its English Translations. Table 1 below displays the types of figurative words identified and highlights the statistics for each type.

Table 1. Types of Figurative Language

\begin{tabular}{|c|c|}
\hline Types of Figurative Language & Number \\
\hline Simile & 1 \\
\hline Idiom & 2 \\
\hline Metaphor & 10 \\
\hline
\end{tabular}

The number and presence of different types of figurative words in the ST as presented in Table 1 above indicate that the academic context of the UniMAP 2015 $\mathrm{VC}^{\mathrm{ce}} \mathrm{S}$ Keynote Speech is certainly characterized by the use of figurative language - in this case idioms, metaphors and similes to describe, explain or express something implicitly or to create a far more effective impact on the readers.

\subsection{Translation Procedures}

In translating simile, the translator maintained the image or element of the ST as illustrated in Table 2. The translator used a simile of similar meaning and form. The phrase ,bagai adat tiada bertukar, rahsia tidak berubah" has a similar meaning with "peas in a pod" and "hand and glove". As demonstrated, both the Malay and English simile refer to the same meaning with a similar use of lexical item.

\section{Table 2. Simile in ST and TT}

\begin{tabular}{|l|l|}
\hline Source text (ST) - Malay & Target Text (TT) - English \\
\hline Bekerja dengan semuanya & Working together as peas \\
bagai adat tiada bertukar, & in a pod, hand and glove, \\
rahsia tidak berubah & and (inseparable). \\
(maknanya perhubungan & \\
kita yang sangat akrab dan & \\
tidak dapat dipisahkan & \\
\hline
\end{tabular}

rather selected non- figurative English words which had a similar meaning. This finding corroborates Larson $\mathrm{s}$ (1998:48-49) view that "a literal word-for-word translation of the idioms into another language will not make sense. The form cannot be kept, but the receptor language word or phrase which has the equivalent meaning will be the correct one to use for translation". As illustrated by the examples below in Table 3, the translator did not perform a "literal word-for-word translation of the idioms rather retained the Malay idiom in the TT and provided an explanation of the idiom in the TT. The wording ,helping one another; the affluent helps those in need, the lettered assists those who are unlettered, and the influential protects those who are powerless $^{\text {ee }}$ is equivalent to the meaning of „Adat Pulau, Limburan Pasange. For the ST idiom "bulat air kerana pembentung, bulat kata", the translator provides an equivalent idiom in the TT that has a similar meaning to the idiom in the ST - a pipe shapes flowing water, consensus shapes flowing words) denoting that a community creates its own destiny.

Table 3. Idiom in ST and TT

\begin{tabular}{|c|c|}
\hline Source text (ST) - Malay & Target Text (TT) - English \\
\hline $\begin{array}{l}\text { 1. } \begin{array}{l}\text { Peribahasa } \\
\text { Melayu ada } \\
\text { menyebut }, \text { Adat }\end{array} \\
\frac{\text { Pulau, }}{\text { Limburan }} \\
\frac{\text { Pasang }}{\text { (maknanya adat }} \\
\text { hidup bantu } \\
\text { membantu; } \\
\text { yang berharta } \\
\text { membantu yang } \\
\text { melata, yang } \\
\text { berilmu } \\
\text { membantu yang } \\
\text { keliru, dan yang } \\
\text { berkuasa } \\
\text { melindungi } \\
\text { yang derita). }\end{array}$ & $\begin{array}{l}\text { There is a Malay proverb } \\
\text { that says 'Adat Pulau, } \\
\text { Limburan Pisang' (which } \\
\text { means helping one } \\
\text { another; the affluent helps } \\
\text { those in need, the lettered } \\
\text { assists those who are } \\
\text { unlettered, and the } \\
\text { influential protects those } \\
\text { who are powerless) }\end{array}$ \\
\hline $\begin{array}{l}\text { 2. Peribahasa } \\
\text { Melayu } \\
\text { mengingatkan } \\
\text { kita bahawa } \\
\text { bulat air kerana } \\
\text { pembentung, } \\
\text { bulat kata } \\
\text { kerana } \\
\text { muafakat. } \\
\text { Begitulah adat } \\
\text { kita. }\end{array}$ & $\begin{array}{l}\text { A Malay proverb reminds } \\
\text { us that bulat air kerana } \\
\text { pembentung, bulat kata } \\
\text { kerana muafakat (a pipe } \\
\text { shapes flowing water, } \\
\text { consensus shapes flowing } \\
\text { words) denoting that a } \\
\text { community creates its own } \\
\text { destiny). Such is our } \\
\text { tradition. }\end{array}$ \\
\hline
\end{tabular}


Table 3 displays the translation of idioms. The translator did not translate the three idioms as a literal translation

Larson, (1998, p.279) states that if an expression is properly understood by the target audience, the metaphor can be translated directly into the target language metaphor. In other words, where it concerns translating metaphors, translators can maintain metaphorical expression with the same image or substituting a different metaphor in the target language carries the same meaning as the metaphor in the SL as illustrated in Table 4 below.

Table 4. Metaphor in ST and TT

\begin{tabular}{|l|l|}
\hline Source text (ST) - Malay & Target Text (TT) - English \\
\hline $\begin{array}{l}\text { 1. darah penyalur tenaga; } \\
\text { nadi penggerak usaha; }\end{array}$ & $\begin{array}{l}\text { the lifeblood, the driving } \\
\text { Pulse }\end{array}$ \\
$\begin{array}{l}\text { 2. dibajai } \\
\text { nourished. }\end{array}$ \\
$\begin{array}{l}\text { 3. subur dengan idea- } \\
\text { idea baru, sentiasa subur } \\
\text { dengan usaha-usaha } \\
\text { penambahbaikan yang } \\
\text { berterusan }\end{array}$ & $\begin{array}{l}\text { fertile with new ideas, } \\
\text { fruitful with constant } \\
\text { Improvements }\end{array}$ \\
\hline
\end{tabular}

As seen in the examples above, the image of the SL metaphor resembles the same image in the TT. The translated image of "darah penyalur tenaga" to "the life- blood"; "nadi penggerak usaha" to the "driving pulse" ; "subur dengan idea-idea baru" to "fertile with new ideas"; "subur dengan usaha-usaha penambahbaikan yang berterusan" to "fruitful with constant improvements" resembles the same image in the TT. The translated image correlates with the image of the target culture and it can be understood by the TT audience.

\section{Limitations of the Study}

This study analysed the translation of figurative language extracted from UniMAP's Vice Chancellor Keynote Speech in 2015. The corpus selected presents as one of the limitations of the study. Firstly, the corpus size is relatively small mainly due to the specific genre, topic of the corpus and problems in identifying the suitable Malay (TT) translation for possible English Source Texts. Secondly, the time which was allocated to the TL translator to perform the translations serves as another limitation. According to the TL translator, the submission deadline was less than twelve hours. As a result, there was not enough time to edit nor consult or refer to more reliable sources to attain a more accurate translation for the problematic figurative words. This to a certain extent may have affected the quality of the translated text.

\section{Conclusion}

Translating figurative language can be trying especially when translating figurative words from one language into another. The challenge arises from the differences between languages in using figurative words and to ensure that the message is conveyed as accurately as possible In other words, figurative language comprise of unique linguistic characteristics and cultural elements that belong to the SL. Therefore, they are difficult to transfer into the TL. The more characteristic they are in the ST, the more complexities they pose for the translators who attempt to re-create the message they convey, their purpose and effect in the TT. The SL figurative words appear in a variety of types and have distinct denotative and connotative meaning and reference. These factors make it difficult for the translator to find a standard equivalent which totally complements the SL figurative meaning or concept. Therefore it is vital for the translator to not only possess a clear understanding and competence in the cultural, social and linguistic features of both the SL and TL figurative language; but also to ensure that the translation procedure adopted does not cause major changes to the structure of the ST.

\section{References}

[1] Montgomery, Mar; Durant, Alan; Fabb, Nigel; Tom Furniss; Sara Mills Ways of Reading: Advanced Reading Skills for Students of English Literature. Taylor \& Francis. pp. 117-. ISBN 9780415346337. (2007)

[2] E. A. Nida, Language Structure And Translation. California, United States: Stanford University Press. (1975)

[3, 25, 36] P.R. Abdul Wahid,. Translation Of Figurative Language From English To Malay: An Analysis Of The Translation Of The Harry Potter Series. Proceedings of Research World International Conference, Phuket, Thailand, 9th-10th February, 2017, ISBN: 978-93-86083-34-0 (2017)

[4, 24, 35] S. Abdullah, Translating Technical Metaphors from English into Malay: Possibilities (and Challenges). Proceedings of Symposium of International Languages and Knowledge. Penang, Malaysia, $14^{\text {th }}-16^{\text {th }}$ February 2017 (2014)

$[5,12]$ R. T. Bell, Translation And Translating, Theory And Practice (pp. 6).London and New York: Longman. (1991)

[6, 8] R. Jakobson, Pëtr Bogatyrëv: Expert in Transfiguration. Michigan Slavic Publications. (1976)

[7, 9, 10, 33] S. Bassnett, Translation Studies (pp. 15 29). London: Routeledge (1980)

[11] P. Newmark, Approaches To Translation (pp. 7). Oxford: Prentice Hall. (1981)

$[13,14]$ B. Hatim, \& J. Munday, Translation: An Advanced Resource Book (pp. 3-6). USA \& Canada Routledge. (2004)

$[15,17]$ M. Shuttleworth, \& M. Cowie, Dictionary Of Translation Studies. Manchester: St Jerome Publishing. (1997)

[15] M. Shuttleworth, \& M. Cowie, Dictionary of Translation Studies. (Reprint Ed). London \& New York:Routledge, Taylor \& Frances Group. (2014) 
[16] S. Abdullah, \& M. Shuttleworth, Metaphors In The Translation Of English Technical Texts In to Malay: A Preliminary Study. Journal of Asian Scientific Research, 3(6), 608-629. (2013)

[18] T. Hermans, "Toury's Empiricism Version One: Review of Gideon Toury's In Search of a Theory of Translation”. In: The Translator, 1:2, pp.215-223. (1995)

[19] R. Jakobson, On Linguistics Aspects Of Translation (pp. 26). Selected Writings. Mouton: The Hague, 260-266. (1959)

[19] R. Jakobson, Selected Writings: Slavic Epic Studies. The Hague, Paris: Mouton \& Co. (1966)

[20] E. A. Nida, Toward A Science Of Translating (pp. 159). Leiden, Netherlands: E.J. Brill. (1964)

[20] E. A. Nida, \& C. R. Taber (1969/1982). The Theory And Practice Of Translation (pp. 200). Leiden: E. J. Brill.

[21] J. C. Catford, A Linguistic Theory On Translation (pp. 27 - 94). (London: Oxford University Press. (1965)

[22, 37-38, 44] M. Baker, A Coursebook On Translation (pp. 217). London: Routledge. (1992)

[23] J.P. Vinay, \& J. Darbelent, A Methodology For Translation.Amsterdam/Philadelphia: John Benjamins. (1995)

[26] C. Nord, (2001). Translating As A Purposeful Activity: Functionalist Approaches Explained. Manchester, U.K.: St Jerome Publishers.

[27, 29] C. Nord, Translating as a Purposeful Activity. Manchester: St Jerome Publishing. (1997)
[28, 31] P. Newmark, A Textbook Of Translation (pp. 48-49, 109). New York: Prentice Hall. (1988a)

[30, 32] M. Dagut, Can "Metaphor" Be Translated”?,in Babel 22:1. 21-33. (1976)

[34] M. Snell-Hornby, Translation Studies: An Integrated Approach (pp. 19). (Revised Ed). Amsterdam \& Philadelphia: John Benjamins Publishing Company (first published 1988). (1995)

[39] K. Shunmugam, The Translation of Metaphors in Malay Pantuns into English, in Proceedings, In Between Wor(l)ds: Transformation and Translation, The University of Melbourne. http://hdl.handle.net/11343/34691 (2007)

$[40,42]$ W.N.H. Wan Ramli, The Translation Of Simile In The Hunger Games Novel: Translation Strategies. (pp. 373-378). E-proceedings of the Conference on Management and Muamalah (CoMM 2014), 26-27 May 2014. Synergizing Knowledge on Management and Muamalah (E-ISBN: 978-983-3048-92-2) (2014)

[41] P. Pierini, Simile in English: From Description to Translation. CÍRCULO de Lingüistica Aplicada a la Comunicación (clac) 29, 21-43. (2007)

[43] H. Subagiharti, et.al. Classical Malay's Anthropomorphemic Metaphors in Essay of Hikajat Abdullah. IOSR Journal of Humanities And Social Science (IOSR-JHSS).Volume 20, Issue 2, Ver. V (Feb. 2015), PP 01-09. e-ISSN: 2279-0837, p-ISSN: 2279-0845. www.iosrjournals.org. (2015)

[45-46] M. L. Larson, Meaning-based translation: A guide to cross language equivalence. Lanham, United States: University Press of America. (1998) 